Przegląd Narodowościowy / Review of Nationalities • nr 7/2017 • World of Slavs / Świat Słowian

\title{
The role of children's literature in the patriotism, and the upbringing of Kurdish children
}

\author{
Rola literatury dziecięcej w patriotyzmie \\ i wychowaniu dzieci kurdyjskich
}

Keywords: Children's literature, Kurdish Children's Literature, Kurdish Culture, Kurdish Nationalism, Role of Education

\section{Introduction}

Assuming that Charlotte Huck, an American professor and expert of children's literature was correct in her considerations, children's books can be defined as those 'that have the child's eye at the center'. The concise definition seems to be obvious, although it needs to be explained.

Is children's literature about what we read to children? Or maybe what children read about? Or maybe both? Does it include solely books, or is an orally transmitted story a part of it also? Is it a modern phenomenon or has it been present in bringing up a child since time immemorial?

Children's literature is a relatively young branch of literature in general. Some

${ }^{1}$ C.H. Huck, B.Z. Kiefer, S. Hepler, J. Hickman, Children's literature in the elementary school, $8^{\text {th }}$ ed., New York 2004, p. 5.
Słowa kluczowe: literatura dziecięca, kurdyjska literatura dziecięca, kultura kurdyjska, nacjonalizm kurdyjski, rola edukacji

Wstęp

Zakładając, że Charlotte Huck, amerykańska profesor i znawca literatury dziecięcej, miała rację w swoich rozważaniach, książki dla dzieci można zdefiniować jako te, „które patrzą na świat okiem dziecka”. Tak zwięzła definicja wydaje się oczywista, chociaż wymaga pewnych wyjaśnień.

Czy literatura dziecięca jest tym, co czytamy dzieciom? A może to, o czym dzieci czytają? A może jedno i drugie? Czy obejmuje ona wyłącznie książki, czy też ustnie przekazywane opowiadanie jest także jej częścią? Czy jest to zjawisko współczesne, czy też jest ona obecna w wychowywaniu dzieci od niepamiętnych czasów?

Literatura dziecięca jest w ogóle stosunkowo młodą literaturą. Niektórzy

${ }^{1}$ C.H. Huck, B.Z. Kiefer, S. Hepler, J. Hickman, Children's literature in the elementary school, $8^{\text {th }} \mathrm{ed}$., New York 2004, s. 5.

* Correspondence address: Dept. of Kurdish Language, College of Basic Education, Kirkuk Road, Erbil 44002, Kurdistan Region / Iraq, e-mail: farhang_rashkini@yahoo.com. 
may say it appeared in 1865 with the release of Lewis Caroll's Alice's Adventures in Wonderland ${ }^{2}$. Others may disagree, pointing to A Little Pretty Pocket-book written in 1744 by British publisher John Newbery as the first book dedicated specifically to children $^{3}$. Some even think that highly moralistic and religiously influenced stories common during The Middle Ages constitute the root of children's literature.

Nevertheless, there is little doubt about the golden age of children's literature, which is commonly considered to last through the nineteenth and twentieth century. During this period the modern form of children's literature developed and received attention from researchers and prominent writers. Certain genres began to form and children's books were no longer only stories. They varied significantly and developed in many ways. Today we can specify at least a dozen genres and subcategories of children's literature such as fairy tales, myths, fables, legends, tall tales, poetry and verse, fantasy, and realistic or historical fiction ${ }^{4}$. It has to be mentioned that there are also works dedicated to beginning readers such as wordless books and easy-to-read books ${ }^{5}$ (with a vocabulary adjusted to the child's skills and needs) in which illustrations constitute a clue to unraveling the message.

\footnotetext{
2 N.A. Anderson, Elementary Children's Literature: The Basics for Teachers and Parents, 2/E, Pearson 2005, p. 4.

3 C.L. Burke, J.G. Copenhaver, Animals as People in Children's Literature, "Language Arts" 2004, Vol. 81 No. 3, p. 208.

4 N.A. Anderson, op. cit., p. 8.

5 Ibidem, p. 12.
}

twierdzą, że pojawiła się w 1865 r. wraz $\mathrm{z}$ wydaniem Alicji w krainie czarów Carla Lewisa ${ }^{2}$. Inni mogą się nie zgadzać, wskazując na książkę Little Pretty Pocket-book napisaną w 1744 r. przez brytyjskiego wydawcę Johna Newbery’ego jako pierwszą książkę dedykowaną specjalnie dla dzieci³. Niektórzy nawet uważają, że wysoce moralistyczne i religijne wpływy opowieści popularne w czasach średniowiecza stanowią podstawę literatury dziecięcej.

Niemniej jednak, powszechnie panuje opinia, że złoty wiek literatury dziecięcej przypada na wiek XIX i XX. W tym okresie nowoczesna forma literatury dla dzieci rozwijała się, przyciągając uwagę naukowców i wybitnych pisarzy. Zaczęły się pojawiać określone rodzaje, a książki dla dzieci nie były już tylko opowieściami. Znacznie się różnicowały i rozwijały na wiele sposobów. Obecnie możemy określić co najmniej kilkanaście gatunków i podkategorii literatury dziecięcej, takich jak: bajki, mity, legendy, niewiarygodne historie, poezja i wiersze, fantastyka i powieść współczesna lub historyczna ${ }^{4}$. Należy wspomnieć, że istnieją również pozycje przeznaczone dla początkujących czytelników, takie jak książki bez słów i książki łatwe w czytaniu $^{5}$ (ze słownictwem dostosowanym do umiejętności i potrzeb dziecka), w których ilustracje stanowią wskazówkę do zrozumienia treści.

\footnotetext{
2 N.A. Anderson, Elementary Children's Literature: The Basics for Teachers and Parents, 2/E, Pearson 2005, s. 4.

3 C. Burke, J.G. Copenhaver, Animals as People in Children's Literature, „Language Arts” 2004, vol. 81, nr 3, s. 208.

4 N.A. Anderson, op. cit., s. 8.

5 Ibidem, s. 12.
} 
Along with the development of children's literature, the attitude towards and perception of childhood in society changed significantly in the eighteenth century. As Burke and Copenhaver argue "the notion of childhood that we know today did not exist". It gradually became clear that childhood was a distinct part of human life with its own specific needs and capabilities that should not be neglected, as they may have a huge impact on personality and the future success of a child.

What are, therefore, the possible benefits of children's literature? Although each child is an individual person, there are many values in the readings that apply to the majority of children. One can point out the expanding of children's vocabulary, imagination and knowledge of the world around them, as well as facing various feelings and emotions. It also creates a bond with the reader and encourages them to read in the future ${ }^{7}$. Many researchers indicate that reading to children increases athe chances of them being successful at school. Despite the fact that all the values mentioned above are important and emphasized by teachers and methodologists, children themselves would probably state clearly that by reading they gain an opportunity to participate in a magic world of adventures with their favorite characters. Entertainment thus should not be underestimated.

Many other values could also be added. All of them are intended to help bring up a child able to fit its place in a family,

\footnotetext{
6 C.L. Burke, J.G. Copenhaver, op. cit., p. 208.

7 N.A. Anderson, op. cit., pp. 19-20.
}

Wraz z rozwojem literatury dla dzieci postawa wobec dzieciństwa i jego postrzeganie znacząco zmieniły się w społeczeństwie w XVIII w. Burke i Copenhaver twierdzą, że „pojęcie dzieciństwa, o którym dzisiaj wiemy, nie istniało" 6 . Stopniowo stało się jasne, że dzieciństwo było odrębną częścią życia ludzkiego z własnymi specyficznymi potrzebami i zdolnościami, których nie należy zaniedbywać, ponieważ mogą one mieć ogromny wpływ na osobowość i przyszły sukces dziecka.

Jakie są zatem potencjalne korzyści z literatury dziecięcej? Chociaż każde dziecko jest indywidualną osobą, większość dzieci może czerpać znaczące korzyści z czytania. Można tu wskazać poszerzenie słownictwa u dzieci, wzbogacenie wyobraźni i wiedzy o otaczającym ich świecie, a także przeżywanie różnych uczuć i emocji. Tworzy to też więź z czytelnikiem i zachęca ich do czytania w przyszłości ${ }^{7}$. Wielu badaczy wskazuje, że czytanie dzieciom zwiększa ich szanse na sukces w szkole. Pomimo tego, że wszystkie wyżej wymienione wartości są ważne i podkreślane przez nauczycieli i metodologów, same dzieci zapewne stwierdzą, że poprzez czytanie mają możliwość uczestniczenia w magicznym świecie przygód ze swoimi ulubionymi postaciami. Rozrywka nie powinna być więc niedoceniana.

Można też wymienić wiele innych wartości. Wszystkie z nich mają pomóc wychować dziecko, które będzie w stanie znaleźć swoje miejsce w rodzinie, społeczności szkolnej i społeczeństwie w ogóle,

\footnotetext{
6 C.L. Burke, J.G. Copenhaver, op. cit., s. 208.

7 N.A. Anderson, op. cit., s. 19-20.
} 
school community and society in general, as well as capable of handling various situations with maturity, following the socially accepted moral or religious patterns and of being a successful and satisfied person.

Although the stories told by parents, teachers and nannies, and later read by children themselves, constitute an element of childhood beloved by children all over the world, particular books and genres may vary, depending on the circumstances surrounding them. History, religion, technological advancement, literacy level, and language status are just a few of the factors that affect children's literature's conditions and contents.

In this research we attempt to analyze the role of children's literature, the times in which that literature and literacy became common, particular motives and characters and their role in bringing up a child. A brief introduction into history will be followed by certain examples to show how time, place and other circumstances affect children's literature, as well as what values remain universal, despite fundamental differences within Kurdish society.

The aim of this research is to explore how in the course of historical development the concept "patriotism" came into contact with education and strengthened several states in their fight for national independence. Thus, it is possible to claim that patriotism has deep roots and is a feeling which is formed, supplemented, and has changed throughout the years ${ }^{8}$.

${ }^{8}$ K.S. Ergobek, A.B. Mukhamedzhanova, D.K. Sartbaeva, A.S. Karpykbaeva, A.K. Bimaganbetova, Patriotic upbringing of future teachers in the a także będzie potrafiło radzić sobie w różnych sytuacjach w sposób dojrzały, zgodnie z przyjętymi społecznie wzorami moralnymi lub religijnymi oraz będzie odnosić sukcesy i będzie spełnione.

Chociaż historie opowiadane przez rodziców, nauczycieli i opiekunki, a później czytane przez same dzieci stanowią element dzieciństwa ukochanego przez dzieci na całym świecie, poszczególne książki i gatunki mogą różnić się w zależności od okoliczności, w których funkcjonują. Historia, religia, postęp technologiczny, poziom umiejętności pisania i język to tylko niektóre z czynników mających wpływ na warunki i treść literatury dziecięcej.

W tych badaniach próbuję przeanalizować rolę literatury dla dzieci, czas, w którym literatura i znajomość języka stały się powszechne, konkretne motywy i postacie oraz ich rolę w wychowaniu dziecka. Po krótkim wprowadzeniu do historii przedstawiam kilka przykładów, aby pokazać, jak czas, miejsce i inne okoliczności wpływają na literaturę dziecięcą, a także jakie wartości pozostają uniwersalne, pomimo fundamentalnych różnic w społeczeństwie kurdyjskim.

Celem tych badań jest przeanalizowanie, jak w trakcie rozwoju historycznego pojęcie patriotyzmu pojawiało się w edukacji i jak wzmacniało niektóre państwa w ich walce o niepodległość. Można więc twierdzić, że patriotyzm ma głębokie korzenie i jest uczuciem, które powstaje, uzupełnia i zmienia się przez lata ${ }^{8}$.

${ }^{8}$ K.S. Ergobek, A.B. Mukhamedzhanova, D.K. Sartbaeva, A.S. Karpykbaeva, A.K. Bimaganbetova, Patriotic upbringing of future teachers in the 


\section{Kurdish nationalism}

The Majority of Kurds are distributed in Turkey, Iran, Iraq and Syria. Its boundaries do not coincide with international frontiers or internal administrative divisions ${ }^{9}$.

There are various factors that play significant role in establishing the Kurdish nationality. These include: international, historical and political ones. "There was no existing Kurdish state to forge a Kurdish national identity. Therefore, the argument that nations and their attachments, like culture and territory, are given and primordial and that these primordial features precede all social and political interaction, appear to be strong in the Kurdish case"10.

The literature on Kurds is mainly composed of in-depth historical analysis of the Kurdish people and histories of the development of Kurdish national identity and Kurdish nationalism. If we go back to the beginning to the emergence of Kurdish children's literature we see that its roots date back to the time long before the Kurdish literary tradition began, although in its written form it can be considered to start with the emergence of the Kurdish dictionary Nûbehara Biçûkan ${ }^{11}$ (The Spring of

course of studying of the discipline "Children's literature", "Life Science Journal" 2014, 11, p. 59.

9 C.J. Edmonds, Kurdish Nationalism, p. 87, http://journals.sagepub.com/doi/abs/10.1177/ 002200947100600105 [access on: 10.10.2016].

10 Z.N. Kaya, Maps into Nations: Kurdistan, Kurdish Nationalism and International Society, London June 2012, p. 36, http://etheses.lse.ac. uk/645/1/Zeynep_Maps_into_Nations.pdf [access on: 11.10.2016].

11 The first text for children, which is the 'didactic poetry' the work was taken on 12.03 .1683 , and it is considered to be the beginning of the Kurdish children literature. Students in the mosques after reading the Koran and save, They Should memorize

\section{Nacjonalizm kurdyjski}

Większość Kurdów żyje w Turcji, Iranie, Iraku i Syrii. Granice tych terenów nie pokrywają się z granicami międzynarodowymi czy wewnętrznymi podziałami administracyjnymi?

Istnieją różne czynniki, które odgrywają znaczącą rolę w ustalaniu obywatelstwa kurdyjskiego. Należą do nich: międzynarodowe, historyczne i polityczne. „Nie istniało wówczas państwo kurdyjskie, które wytworzyłoby kurdyjską tożsamość narodową. Dlatego też argument, że narody i ich spoiwa, takie jak kultura i terytorium, są podstawowe i pierwotne i że te pierwotne cechy poprzedzające wszystkie interakcje społeczne i polityczne okazują się istotne w przypadku Kurdów"10.

Literatura dotycząca Kurdów składa się głównie z pogłębionej analizy historycznej narodu kurdyjskiego i historii rozwoju kurdyjskiej narodowej tożsamości i nacjonalizmu kurdyjskiego. Jeśli wrócimy do początków pojawienia się kurdyjskiej literatury dziecięcej, widzimy, że jej korzenie sięgają czasów, zanim zaczęła się tradycja literatury kurdyjskiej, chociaż za jej początek w formie pisanej można uznać moment pojawienia się słownika kurdyjskie-

course of studying of the discipline "Children's literature”, „Life Science Journal” 2014,11, s. 59.

9 C.J. Edmonds, Kurdish Nationalism, s. 87, http://journals.sagepub.com/doi/abs/10.1177/00 2200947100600105 [dostęp: 11.10.2016].

10 N.K. Zeynep, Maps into Nations: Kurdistan, Kurdish Nationalism and International Society, London School of Economics and Political Science, London, June 2012, p. 36, http://etheses.lse. ac.uk/645/1/Zeynep_Maps_into_Nations.pdf [dostęp: 11.10.2016]. 
Children) of the great poet Ahmadi Khani (1650-1706) that was aimed at children ${ }^{12}$. The purpose of writing (Nûbehara Biçûkan) by Ahmadi Khani was to teach Kurdish children the Kurdish language for use in the mosque. He also wanted to give great importance to the Kurdish language. Ahmedi Khani was known for his writings on patriotism and his ideas of nationalism. $\mathrm{He}$ is considered as a first national poet who writes a national poetry and in (Mam $\mathrm{u}$ Zain $)^{13}$ he expresses his views and nostalgic love of his homeland and about the unity of Kurds against enemies ${ }^{14}$.

There have also been other poets with similar attempts to satisfy children's literary needs, such as Sheykh Marfi Nodi (1753-1838) who wrote Ahmedi, especially for children and students of the mosque in the mid-eighteenth century. The work consists of 365 verses of didactic poetry aimed at helping them learn Arabic ${ }^{15}$.

poetry on book 'Nûbehara Biçûkan'. See: H. Hawrami, Adabi Mndalany Kurd Lekolinawaw. Mejuy Sarhaldan, p. 161.

${ }^{12}$ S. Nakshaband, A History of Kurdish Children's Literature, Paper presented at the EU - International P.E.N Conference Language, Literature and Culture of the kurdish People, Brussels 9-10 December 1999, translated by Dr. Zorab Aloian.

${ }^{13} \mathrm{Mem}$ and Zin is a tragic love story reminiscent of Romeo and Juliet. Oral versions of it have been collected by European Orientalists from as early as the middle of the $19^{\text {th }}$ century, and a poem based on it was written down by the great Kurdish poet Ahmed-i Khani in the 17th century. Neo-Aramaic and Armenian versions of it also exist. The Kurdish Project, http://thekurdishproject.org/history-andculture/kurdish-culture/kurdish-folklore/ [access on: 10.10 .2016 .

14 A. al-sajadi, Meju-y adab-i kurdi, chapxanay maarf, Bagdad 1971, p. 229.

${ }^{15}$ H. Hawrami, Adabi Mndalany Kurd Lekolinawaw. Mejuy Sarhaldan, Hawler 2005, p. 161. go (Nûbehara Biçûkan) ${ }^{11}$ wielkiego poety Ahmadi Khani (1650-1706), skierowanego do dzieci ${ }^{12}$. Dla Ahmadi Khani celem napisania tej książki (Nûbehara Biçûkan) było nauczanie kurdyjskich dzieci języka kurdyjskiego do wykorzystania w meczecie. Chciał również nadać duże znaczenie językowi kurdyjskiemu. Ahmadi Khani znany był z pism o patriotyzmie i swoich ideach nacjonalizmu. Jest uważany za pierwszego narodowego poetę, który pisał o narodowej poezji. W Mem i Zin ${ }^{13}$ prezentuje on swoje poglądy i nostalgiczną miłość do swojej ojczyzny oraz pisze o jedności Kurdów przeciwko wrogom ${ }^{14}$.

Byli też inni poeci, którzy próbowali wyjść naprzeciw literackim potrzebom dzieci, jak Sheykh Marfi Nodi (1753-1838), który napisał Ahmedi, zwłaszcza dla dzieci i studentów meczetu w połowie XVIII w.

11 Jeżeli przyjrzymy się książce Nûbehara Biçûkan (Nowe źródło dla młodych), możemy zauważyć, że ma ona ogromne znaczenie w literaturze kurdyjskiej. Noubehara Biçûkan, napisana przez Ahmada Khani, jest pierwszym tekstem dla dzieci, a dokładniej „poezją dydaktyczną”. Została ona napisana 12 marca 1683 r. i jest uważana za początek kurdyjskiej literatury dla dzieci. Studenci w meczetach po przeczytaniu Koranu i zapisania, powinni zapamiętać poezję z książki Nûbehara Biçûkan.

12 S. Nakshaband, A History of Kurdish Children's Literature, artykuł zaprezentowany na Konferencji Jezykowej EU - International P.E.N: Literature and Culture of the Kurdish People, Bruksela, Belgia 9-10 grudnia 1999, przetłumaczone przez dr. Zorab Aloian.

${ }^{13}$ Mem i Zin to tragiczna historia miłosna przypominająca Romeo i Julię. Wersje ustne zostały zebrane przez europejskich orientalistów już w połowie XIX w., a w XVII w. wielki kurdyjski poeta Ahmed-i Khani napisał wiersz na jego podstawie. Istnieje również wersja neo-aramejska i ormiańska. The Kurdish Project, http://thekurdishproject. org/history-and-culture/kurdish-culture/kurdish-folklore/ [dostęp: 12.10.2016].

14 A. al-sajadi, Meju-y adab-i kurdi, chapxanaymaarf, Badgdad 1971, s. 229. 
A booklet titled Rola bzani written in the Hawramî dialect by Mullah Khedr Rawi (1721-1781) should be mentioned as well, as it served as a mean to learn the principles of the Islamic religion ${ }^{16}$. These works constitute the beginning of Kurdish children's literature.

\section{What about Kurdish folklore?}

Folklore is concerned with the rural people and it continued to exist for a long time ${ }^{17}$. It concentrates on the oral tradition of the cultural aspect of these people. Such cultural aspect continues for a long time and takes into consideration the formal institutions such as schools, universities and other academic places ${ }^{18}$.

Considering the first literary texts, we cannot separate literature for children from popular literature. These folkloric literary works that were made for children included in their content different types of literary arts and are considered an independent Kurdish folklore in literature ${ }^{19}$. Kurdish folklore has had a significant impact on raising children. The children's stories of Kurdish folklore literature and its topics are important factors that influence Kurdish children and their identity.

16 Ibidem, p. 164.

17 D. Noyes, The Social Base of Folklore, [in:] A Companion to Folklore, edit. R. Bendix, G. HasanRokem, Malden 2012, pp. 15-16.

18 Eabd alnabi Aistif, Al'adab Alshaebi, https:// www.arab-ency.com/ar/ [access on: 10.10.2016].

19 N. Ahmad, Saratayak darbaray sarhaldani adabi mndalani kurd, Hewler 2005, p. 8.
Praca składa się z 365 wersetów poezji dydaktycznej, które mają pomóc im nauczyć się języka arabskiego ${ }^{15}$.

Należy również wspomnieć o broszurze zatytułowanej Rola bzani, napisanej w dialekcie Hawrama przez Mullaha Khedr Rawi (1721-1781), która służyła do nauki zasad religii islamskiej ${ }^{16}$. Prace te stanowią początek kurdyjskiej literatury dziecięcej.

\section{A co z folklorem kurdyjskim?}

Folklor dotyczy ludności wiejskiej i istnieje od dawna ${ }^{17}$. Koncentruje się na ustnej tradycji kulturowego aspektu tych ludzi. Taki aspekt kulturowy trwa przez długi okres i uwzględnia formalne instytucje, takie jak szkoły, uniwersytety i inne instytucje akademickie ${ }^{18}$.

Biorąc pod uwagę pierwsze teksty literackie, nie możemy oddzielić literatury dla dzieci od literatury popularnej. Te folklorystyczne dzieła literackie, napisane dla dzieci w różnych rodzajach literackich, są uważane za niezależny folklor kurdyjski w literaturze ${ }^{19}$. Miał on znaczący wpływ na wychowywanie dzieci. Opowieści dla dzieci w literaturze folkloru kurdyjskiego i ich tematyka są ważnymi czynnikami, które mają wpływ na dzieci kurdyjskie i ich

15 H. Hawrami, Adabi Mndalany Kurd Lekolinawaw, Mejuy Sarhaldan, Koriyanzari Kurdistan, Hawler 2005, s. 161.

16 Ibidem, s. 164.

17 D. Noyes, The Social Base of Folklore, [w:] A Companion to Folklore, red. R. Bendix, G. HasanRokem, Malden 2012, ss. 15-16.

18 E. Aistif, Al'adab Alshaebi, https://www.arab-ency.com/ar/ [dostęp: 10.10.2016].

19 N. Ahmad, Saratayak darbaray sarhaldani adabi mndalani kurd, Hewler 2005, s. 8. 
Kurdish folklore literature is very rich and full of stories and tales for children, and as can be noticed, we often find in these stories that the heroes are animals, which is a common theme in the Kurdish story ${ }^{20}$.

The Kurdish folklore which is almost completely oral, is incredibly rich and diverse, its stories are interesting for children who listen while sitting around their parents who narrate such stories. For example, the story Titila $u$ Bibila shows a goat and her cubs facing a wolf. This story is supposed to teach children that good forces should triumph over evil.

Uncle Fox (Mam Rioy) is plentiful in stories dedicated to children such as The story of a fox with a person, The story of a fox with a horse, The story of a fox with a bird, The story of a fox with nature etc. In all those stories, the fox is famous for using gimmicks and deception ${ }^{21}$.

It is no doubt that Kurdish children love these kinds of folklore stories because they entertain and capture their attention. The moral component in these kinds of folk stories for children are derived from the Kurdish community. In early childhood it was traditionally a grandmother or mother that told the stories to children. They explained mysterious things to children, advised them, instructed them and guided their upbringing. After the end of the narrative part of the story the children asked their questions ${ }^{22}$. An example of the masterpieces is Memu and Zin and

20 N. Ali Ameen, Mndal u Adab, Sulaymaniya 2006, p. 35.

21 Ibidem, p. 38.

22 Ibidem, p. 39. tożsamość. Kurdyjska literatura folklorystyczna jest bardzo bogata i pełna opowieści oraz bajek dla dzieci, w których bohaterami są zwierzęta, co jest typowym motywem w kurdyjskich historiach ${ }^{20}$.

Kurdyjski folklor, przekazywany głównie w ustnej formie, jest bogaty i zróżnicowany. Te opowieści są interesujące dla dzieci, które słuchają, siedząc wokół swoich rodziców opowiadających takie historie. W piśmiennictwie kurdyjskim znane są także Historie od Serca (Chiroki ber agrdan). Na przykład opowiadanie Titila u Bibila ukazuje kozę i jej kocięta, które napotkały wilka. Ta opowieść ma nauczyć dzieci, że dobre siły powinny triumfować nad złem.

Wujek Lis (Mam Rioy) jest bogaty w historie poświęcone dziecku, takie jak Opowieść o lisie z człowiekiem, Opowieść o lisie z koniem, Opowieść o lisie z ptakiem, Opowieść o lisie $z$ natura itp. We wszystkich tych opowieściach lis jest znany ze stosowania sztuczek i oszukiwania ${ }^{21}$.

Nie ulega wątpliwości, że dzieci kurdyjskie kochają takie historie folklorystyczne, ponieważ bawią one i przyciągają uwagę. Element moralny w tego typu opowieściach ludowych pochodzi od społeczności kurdyjskiej. W tradycji to właśnie babcie lub matki opowiadały małym dzieciom takie historie. Wyjaśniały im tajemnicze sprawy, doradzały, pouczały i ukierunkowywały ich wychowanie. Po zakończeniu narracyjnej części takiej opowieści dzieci zadawały pytania ${ }^{22}$. Przykładem takich

\footnotetext{
20 N. Ali Ameen, Mndal u Adab, Sulaymaniya 2006, s. 35.

21 Ibidem, s. 38.

22 Ibidem, s. 39.
} 
Khej and Siyamend ${ }^{23}$ Dimdim $^{24}$ and Zembilfrosh ${ }^{25}$.

The latter is about and old woman's love for a young basket seller. It is similar of Zuleikha's love for Joseph. Many folktales feature the adventures of a baldheaded boy, known as Keçelok; the Turks have a similar figure known as Keloğlan, and the Persians and the Azerbaijanis call him Kachal ${ }^{26}$.

\section{Kurdish children stories}

Kurdish children's stories appeared in Kurdish literature in the second half of the twentieth century. One of the most important pioneers of Kurdish children's stories was prince Celadet Bedir Khan (18931951) known by various nicknames, such as "Cîrok bêj" meaning literally the storyteller in the Kurmanji dialect. Despite the fact that childhood was the core interest of his poetry, the significance of these early children's stories lies in magnificence and beauty in terms of content and style, brilliant plots, pure language and strong images. Subsequent fascinating stories were created by Dr. "Kameran Badrkhan (1895-

23 Khej and Siyabend is another romance with a tragic ending.

24 Dimdim is an epic based on a historical event, the insurrection of the Kurds against the Safavid Persian ruler Shah Abbas I in the $16^{\text {th }}$ century: a battle was fought at the fortress of Dimdim, located south of Lake Urmiah (Reza'iyeh) in Iran.

25 Zembilfirosh ('basket-seller' in Kurdish) is a long poem that tells of an older woman's love for a young basket-seller; it is similar to the biblical story of Joseph and Potiphar's wife (Yusuf and Zuleikha), which is also very popular among Middle Eastern peoples, particularly the Kurds.

26 The Kurdish Project, http://thekurdishproject. org/history-and-culture/kurdish-culture/kurdishfolklore/ [access on: 12.10.2016]. arcydzieł są Mem i Zin oraz Khej i Siyamend $^{23}$, Dimdim $^{24}$ i Zembilfrosh ${ }^{25}$.

Ten ostatni jest o miłości staruszki do młodego sprzedawcy koszy. Podobnie jest z miłością Zulejki do Józefa. Wiele ludowych opowieści zawiera przygody łysego chłopca, zwanego Keçelokiem; Turcy mają podobną postać znaną jako Keloğlan, a Persowie i Azerbejdżanie nazywają go $\mathrm{Kachal}^{26}$.

\section{Kurdyjskie opowiadania dla dzieci}

Kurdyjskie opowiadania dla dzieci pojawiły się w literaturze kurdyjskiej w drugiej połowie XX w. Jednym z najważniejszych pionierów kurdyjskich opowieści dla dzieci był książę Celadet Bedir Khan (1893-1951) znany z różnych pseudonimów, np. „Cîrokbêj”, co znaczy dosłownie opowieść w dialekcie Kurmanji. Pomimo tego, że dzieciństwo było w centrum zainteresowań jego poezji, znaczenie tych pierwszych opowieści dla dzieci wynika ze wspaniałości i piękna pod względem treści i stylu, genialnych dziełek, czystego języka i wyrazistych obrazów. Kolejne fascynują-

23 Khej i Siyabend to kolejny romans z tragicznym zakończeniem.

24 Dimdim jest eposem opartym na wydarzeniu historycznym, powstaniu Kurdów przeciwko safawidzkiemu władcy Persji Szachowi Abbasowi I w XVI w.: bitwa odbyła się wokół twierdzy Dimdim, położonej na południe od jeziora Urmiah (Reza'iyeh) w Iranie.

25 Zembilfrosh (sprzedawca koszy) to długi wiersz, który mówi o miłości starszej kobiety do młodego sprzedawcy koszy; jest podobny do biblijnej opowieści o żonie Józefa i Potipara (Jusuf i Zulejka), bardzo popularnej wśród ludów Bliskiego Wschodu, szczególnie Kurdów.

26 The Kurdish Project, http://thekurdishproject.org/history-and-culture/kurdish-culture/kurdish-folklore/ [dostęp: 12.10.2016]. 
1978), Mustafa Ahmed Poti and Shaker Fattah" (1914-1988). Nevertheless, it was "Shaker Fattah" (1914-1988) who stressed the role of education for the Kurds and displayed interest in developing children and expanding their own literature. One of his collections Hawrey Mndalan "Friend of Children" consists of short stories translated from Arabic, while another "Lajer Khorda "Under the Sun", published in 1947, criticizes the old patriarchal and religious order in the Kurdish community. Shaker Fattah also wrote "Flags Prominent" in 1948, which depicts various scientists and artists that have contributed to the enrichment of human civilization. Couched in the form of great literary articles and characterized by simplicity of language and freshness of style, it constituted an exception to the traditional methods of expression ${ }^{27}$.

Due to the Iraqi-Kurdish Autonomy Agreement of $1970 \mathrm{~s}^{28}$ is considered The Golden Age of Kurdish children's literature $^{29}$. The children's stories have the characteristics of constructive elements through which the child learns the art of

27 A.-M. Qasim, Qsas Al-atfal w tajarb kurdiya http://gilgamish.org/printarticle.php?id=2689 [access on: 11.10.2016].

28 Iraqi-Kurdish Autonomy Agreement of 1970 was an agreement, which the Iraqi government and the Kurds reached in March 1970, in the aftermath of the First Kurdish-Iraqi War, for the creation of an Autonomous Region, consisting of the three Kurdish governorates and other adjacent districts that have been determined by census to have a Kurdish majority. The plan also gave Kurds representation in government bodies, to be implemented in four years. See: G.S. Harris, Ethnic Conflict and the Kurds, "Annals of the American Academy of Political and Social Science” 1977, Vol. 433, Issue 1, pp. 118-120.

29 H. Husayni, Darwazayak bo Rakhnay Adabi nwey Kurdi, Hawler 2010, p. 172. ce historie stworzyli dr Kameran Badrkhan (1895-1978), Mustafa Ahmed Poti i Shaker Fattah" (1914-1988). Niemniej jednak to właśnie Shaker Fattah (1914-1988) podkreślał rolę edukacji Kurdów, wykazywał zainteresowanie rozwojem dzieci i rozwijaniem ich własnej literatury. W skład jednej z jego kolekcji Hawrey Mndalan („Przyjaciel dzieci”) wchodzą opowiadania przetłumaczone z języka arabskiego, podczas gdy inna, Lajer Khorda („Pod słońcem”), wydana w 1947 r., krytykuje stary patriarchalny i religijny porządek w społeczności kurdyjskiej. Shaker Fattah napisał także książkę Flags Prominent w 1948 r., przedstawiającą różnych naukowców i artystów, którzy przyczynili się do rozwoju cywilizacji. Ukształtowana $\mathrm{w}$ formie wielkich literackich artykułów, charakteryzująca się prostotą języka i świeżości stylu, stanowiła wyjątek w stosunku do tradycyjnych metod przekazu ${ }^{27}$.

Ze względu na Iracko-Kurdyjskie Porozumienie o Wolności z $1970 \mathrm{r}^{28}$ okres ten uważany jest za Złoty Wiek kurdyjskiej

27 A.-M. Qasim, Qsas Al-atfal w tajarbkurdiya, http://gilgamish.org/printarticle.php?id=2689 [dostęp: 11.10.2016].

28 Porozumienie w sprawie iracko-kurdyjskiej autonomii z 1970 r. było porozumieniem, które rząd iracki i Kurdowie osiągnęli w marcu 1970 r., jako pokłosie pierwszej wojny kurdyjsko-irackiej. Miano utworzyć Region Autonomiczny, składający się $\mathrm{z}$ trzech kurdyjskich regionów i innych przyległych okręgów, które zostały wskazane na podstawie spisu powszechnego jako zamieszkałe przez większość kurdyjską. Ten plan zakładał również przedstawicielstwo Kurdów w organach rządowych, co miało być wdrożone w ciagu czterech lat. Zob. G.S. Harris, Ethnic Conflict and the Kurds, „Annals of the American Academy of Political and Social Science” 1977, Vol. 433, Issue 1, s. 118-120. 
life. Through the story children come to understand lessons and socially desirable behavior in an interesting way, devoid of commands and prohibitions. The story works to expand the imagination of a child, as well as encourages independence and creative inclinations.

Among the most famous Kurdish animal stories are the stories: Hen and the fox (mryshka qwnda u rewy), Foxs and Sheep (gwrg w barkh) snake uncle Omar (marekay mam Omer) etc.

In the world literature the most famous animal stories are the stories attributed to AesoP, the ancient Greek writer who lived centuries before $\mathrm{BC}$, although some scholars said that he has no real presence. He is of Ethiopian origin, just as the word "AesoP" is a collection of stories, which, like all narrated stories on the tongue of the animal, provide useful moral advice, and that Most of the characters are animals that speak and act like humans, and each story ends with a summary of its moral significance $^{30}$. Another content of Kurdish children stories its Heroic and adventure stories which Includes stories which revolve around championships, struggles, leaders and heroes of Kurdish society, Who had a significant influence on the historical course of the Kurdish people Examples of such stories are: Kawa blacksmith (Kawa-y asngar), Khani Golden Palm (Khani lap-zerin), Rostami Zal, Dimdim Castle (Qalay Dimdim), Princess Khanzad Al-Sorani (Khanzada khani soran), Salaheddin Al-Ayyubi, the twelve knights (dwanza swara-y mariwan) and dozens of

\footnotetext{
30 See. Aesops Fables, http://history-world.org/ Aesops_Fables_NT.pdf [access on: 12.10.2016].
}

literatury dla dzieci ${ }^{29}$. Historie dla dzieci charakteryzują się konstruktywnymi elementami, dzięki którym dziecko uczy się sztuki życia. Dzięki opowieściom dzieci mogą zrozumieć treści nauczania i zaakceptować społecznie pożądane zachowania, bez stosowania poleceń i zakazów. Takie opowiadanie działa poprzez rozszerzenie wyobraźni dziecka, a także zachęca do niezależności i kreatywności.

Do najsłynniejszych kurdyjskich opowiadań o zwierzętach należą historie: Kura $i$ lis (Mryshkaqwnda u rewy), Lisy i owce (Gwrg w barkh), Wąż wujek Omar (Marekay mam Omer) itd.

W literaturze światowej najsłynniejsze opowieści o zwierzętach to opowieści przypisywane Ezopowi, starożytnemu greckiemu pisarzowi, który żył wiele wieków przed naszą erą, chociaż niektórzy badacze stwierdzili, że nigdy nie istniał. Ma pochodzenie etiopskie, podobnie jak słowo „Aesop”. Ezopowi przypisuje się zbiór opowiadań, które dostarczają użytecznych wskazówek moralnych, a większość postaci to zwierzęta mówiące i działające jak ludzie. Każda taka opowieść kończy się morałem ${ }^{30}$. Inną tematyką kurdyjskich opowiadań dla dzieci są heroiczne i przygodowe historie, opowiadające o mistrzostwach, walkach, przywódcach i bohaterach społeczności kurdyjskiej, którzy wywarli znaczący wpływ na historyczny rozwój narodu kurdyjskiego. Przykłady takich opowieści to: Kowal Kawa (Kala-y asngar), Khani Złota Ręka (Khani lap-ze-

29 D. H. Husayni, Darwazayak bo Rakhnay Adabi nwey Kurdi, Hawler 2010, s. 172.

30 Zob. Aesops Fables, http://history-world.org/ Aesops_Fables_NT.pdf [dostęp: 12.10.2016]. 
other Kurdish stories. All these stories that we mentioned earlier are taught in schools in the elementary stages in the curriculum in the Kurdistan region.

Among the most famous Kurdish writers of children's stories are Latif Helmat (1947-), Kamal Miriaudali (1951-), Fahraydun Ali Ameen (1933-1992) and others. The frequent places present in writing are villages, forests, homes and school.

\section{The educational role of story in children's lives}

The story plays a big role in the composition of the child's personality, as well as assisting them in adapting to the society in which they live. In the stories the children are provided with social values, customs and traditions that prevail in the community ${ }^{31}$. Religious stories are the most important kinds of children's stories and the most prevalent and influential in the minds of the child. If well written, it is possible to contribute to the religious upbringing of the child and improve their religious concepts dealing with worship, beliefs about the life of the prophets, the stories of the Koran, the life of the Prophet and ethics it gives them ideal role models, entrenching in them faith and unity of God. Through religious stories children are supplied with

31 I.I. El Mosherfy, Adab Al-atfal Madkhal Liltarbiya Al-ibdaeya, Alexandria 2005, p. 59. rin), Rostami Zal, Zamek Dimdim (Qalay Dimdim), Księżna Khanzad Al-Sorani (Khanzadakhanisoran), Salaheddin Al-Ayyubi, Dwunastu rycerzy (Dwanzaswara-mariwan) i dziesiątki innych. Wszystkie te historie, o których wspominałem wcześniej, są nauczane w kurdyjskich szkołach na podstawowym etapie nauczania.

Do najsłynniejszych pisarzy kurdyjskich literatury dziecięcej można zaliczyć takich twórców, jak: Latif Helmat (ur. 1947), Kamal Miriaudali (ur. 1951), Fahraydun Ali Ameen (1933-1992) oraz innych. Najczęściej przedstawiane miejsca w ich twórczości to wioski, lasy, domy i szkoły.

\section{Edukacyjna rola opowiadań w życiu dzieci}

Opowiadanie odgrywa dużą rolę w kształtowaniu osobowości dziecka, a także pomaga im dostosować się do społeczeństwa, w którym żyją. W opowiadaniach dzieci wyznają wartości społeczne, zwyczaje i tradycje, które dominują w społeczeństwie $^{31}$. Opowieści religijne są najważniejszym rodzajem opowiadań dla dzieci, najbardziej rozpowszechnionym i wpływającym na umysł dziecka. Jeśli są dobrze napisane, mogą przyczynić się do religijnego wychowania dziecka i zrozumienia pojęć religijnych dotyczących kultu, wierzeń o życiu proroków, opowieści o Koranie, życiu Proroka i etyki. Dają dzieciom idealne wzorce, umacniając $\mathrm{w}$ nich wiarę i jedność z Bogiem. Poprzez historie religijne dzieci zapoznają się ze zrozumiałym pojęciem religii i jedności, odnoszących się

31 I.I. El Mosherfy, Adab Al-atfal Madkhal Liltarbiya Al-ibdaeya, Alexandria 2005, s. 59. 
a clear idea of religion and oneness, relating to the Holy Quran and the Sunnah. They also provide children with knowledge about healthy habits that enable their healthy physical growth, as well as carries general information and facts about the various communities and the world around them. What is more, in the stories children are provided with scientific facts and laws and link them to different scientific developments. Battle stories and national stories instill patriotism in the hearts of children, leading to the preservation of the state and loyalty to it. In the stories scientists are shown along with their innovations and their merits, and the scientists become serious role models for children. Stories in puzzles, science fiction and fiction are meant to train children to remember and to focus their attention and imagination, to link the incidents to public life and to master the ability to solve the problems they face using judgment, good reasoning and conclusion.

Stories play a great role in the development of the sung, spoken and written language of children and in the increase of the wealth of language they have. Also, the development of literary appreciation in children develops an awareness of the meanings and the methods of literary beauty, talent and the ability to detect them. The story allows children to spend their leisure time on what is useful and entertaining, eliminating the boredom and ennui that they could suffer from, as well as develops a love for reading ${ }^{32}$. do Świętego Koranu i Sunny. Zapewniają także dzieciom wiedzę na temat zdrowych nawyków umożliwiających zdrowy wzrost fizyczny, a także zawierają informacje ogólne i fakty dotyczące różnych społeczności i otaczającego ich świata. Co więcej, w opowiadaniach dzieci poznają naukowe fakty i prawa oraz łączą je z różnymi osiągnięciami naukowymi. Opowieści o bitwach i historie narodowe wpajają patriotyzm w serca dzieci, co prowadzi do umocnienia państwa i lojalności wobec niego. W opowieściach naukowcy są pokazywani wraz z ich innowacjami i zaletami, stając się poważnymi wzorami dla dzieci. Opowieści w zagadkach, science fiction i proza mają na celu ćwiczenie pamięci dzieci i koncentrowanie ich uwagi i wyobraźni, łączenie wydarzeń z życiem publicznym i opanowanie umiejętności rozwiązywania problemów, z którymi się zmagają, przy użyciu ich osądu, dobrego rozumowania i wnioskowania.

Opowiadania odgrywają znaczącą rolę w rozwoju śpiewu, mówionego i pisanego języka dzieci i w zwiększaniu bogactwa języka. Literatura rozwija u dzieci świadomość jej znaczenia i piękna, talent i zdolność do jej odkrywania. Opowiadanie umożliwia dzieciom spędzanie wolnego czasu nad tym, co jest przydatne i rozrywkowe, eliminując nudę i znużenie, a także rozwija miłość do czytania ${ }^{32}$.

32 Ibidem, p. 60.

32 Ibidem, s. 60. 


\section{The Kurdish Children's Poetry}

Poetry is another kind of literary genre which deals with children's' writers ${ }^{33}$ and is a distinct literary form in which children find themselves in a fantasy where they soar ${ }^{34}$. In addition, it meets physical and emotional needs, as it is a serious art in children's literature that contributes to their mentality and morality, both psychological and social ${ }^{35}$. Poetry takes a variety of forms and may be in the shape of a song or anthem, lyric or poetic drama, story or poem $^{36}$. The first children's poetry written by Emin Ali Bedrikhan (1851-1926), entitled Delaliya Zarokan was published in the Kurdistan journal, in 1919 in Istanbul. The poems were written in the form of the seven stanza lullabies of lawandin-ewe ${ }^{37}$.

At the beginning of the twentieth century a group of poets such as Goran (19041962), Which he wrote (Ciq u niq, Mam chawandar ect). Bekas (1903-1948) Which he wrote (Jute kotr u boqek, Du pshila ect.), and Dildar (1917-1948) the owner of the Kurdish national anthem (Ay raqib) appeared and wrote poetry for the children in the collection of Diwans. They studied the poetry of prominent poets such as Peramerd (1867-1950) Rewi u kalasher, Qalabachka w baxawan, Hardi (19222006), and Abdulwahid nuree (1904-1944) in schools. The poetry expresses a love of country and science. Faraydun Ali Ameen (1933-1992) wrote for children in the 1960s, followed by Kakay Fahlah (1928-

\footnotetext{
33 Ibidem, p. 96.

34 Ibidem, p. 97.

35 Ibidem, p. 98.

36 Ibidem, p. 103.

37 H. Hawrami, op. cit., p. 167.
}

\section{Kurdyjska poezja dlla dzieci}

Dla dzieci pisali również kurdyjscy poeci ${ }^{33}$. Poezja jest odrębną formą literacką, wprowadzającą dzieci w świat fantazji, gdzie mogą rozwijać wyobraźnię $e^{34}$. Ponadto zaspokaja ona potrzeby fizyczne i emocjonalne, ponieważ stanowi zbiór poważnych dzieł w literaturze dla dzieci, przyczyniając się do rozwoju ich umysłu i moralności, zarówno w sensie psychologicznym, jak i społecznym ${ }^{35}$. Poezja przybiera różne formy i może mieć kształt pieśni lub hymnu, dramatu lirycznego lub poetyckiego, opowieści lub poematu ${ }^{36}$. Pierwszy tom poezji dla dzieci, który napisał Emin Ali Bedrikhan (1851-1926), zatytułowany Delaliya Zarokan, został opublikowany w kurdyjskim czasopiśmie w 1919 r. w Stambule. Wiersze zostały napisane w postaci siedmiozwrotkowych kołysanek lawandin-ewe $e^{37}$.

Wśród kurdyjskich poetów urodzonych na początku XX w. można wyróżnić takich twórców jak: Goran (1904-1962) (Ciqu niq, Mam chawandar etc.), Bekas (1903-1948) (Juta kotr u boqek, Du pshila etc.) i Dildar (1917-1948), autor kurdyjskiego hymnu narodowego (Ay raqib), który napisał poezję dla dzieci w serii „Diwanie”. Studiowali oni poezję wybitnych poetów, takich jak: Peramerd (1867-1950) (Rewi u kalasher, Qalabachka w baxawan), Hardi (1922-2006) i Abdulwahid nuree (1904-1944). W poezji wyraża się miłość do ojczyzny i nauki. Faraydun Ali Ameen

\footnotetext{
33 Ibidem, s. 96.

34 Ibidem, s. 97.

35 Ibidem, s. 98.

36 Ibidem, s. 103.

37 H. Hawrami, op. cit., s. 167.
} 
1990) in the seventies, and Latif Halmat (1947-) and Abdullah Pashew (1947-) in the eighties ${ }^{38}$ Today Kazim Koye (1957-) is considered one of the most prominent children's poets in Kurdistan.

\section{The educational role of poetry in the lives of Kurdish children}

Poetry has played a big role in the development, education and upbringing children. It is also fun and an exciting joy inside a child. It enriches a child's imagination and develops his abilities to invent. It gives them words and structures that develop their linguistic wealth and helps them use the language properly ${ }^{39}$. Kurdish Children learn poetry in kindergarten and school, The school has great role In educating and raising children, And this role begins with the first enrollment of the child at school and no one can deny such this role. Erbil first school was the first public school in the Erbil in kurdistan, officially opened in 1930, and was able to graduate many educated generations and dozens of personalities and intellectuals, noting that the first Erbil school was embracing Jews, Christians, Muslims, Kurds, Arabs and Turkmen without any discrimination.

In Sulaymaniyah The first school for girls was opened in 1946 by (Habsa Khan Naqib), The opening of schools in Kurdistan it causes to the development of children's literature specially poetry. Because in the schools teach children Nation-

\footnotetext{
38 N. Ali Ameen, op. cit., p. 21.

39 I.I. El Mosherfy, op. cit., p. 104.
}

(1933-1992) pisał dla dzieci w latach 60., Kakay Fahlah (1928-1990) w latach 70., a Latif Halmat (1947-) i Abdullah Pashew (1947-) w latach 80. ${ }^{38}$ Dzisiaj Kazim Koye (1957-) jest uważany za jednego z najwybitniejszych poetów piszących dla dzieci w Kurdystanie.

\section{Edukacyjna rola poezji w życiu kurdyjskich dzieci}

Poezja odgrywa dużą rolę w rozwoju, edukacji i wychowaniu dzieci. To także zabawa dla dziecka wywołująca podekscytowanie i radość. Wzbogaca wyobraźnię dziecka i rozwija jego umiejętności kreatywnego myślenia. Daje mu słowa i struktury, wzbogacając język i pomagając w jego prawidłowym użyciu ${ }^{39}$. Kurdyjskie dzieci uczą się poezji w przedszkolu i szkole, która odgrywa znaczącą, niepodważalną rolę w uczeniu i wychowaniu dzieci, poczynając od pierwszego dnia. Pierwsza publiczna szkoła w Erbil w Kurdystanie oficjalnie została otwarta w 1930 r. Ukończyło ją wiele wykształconych pokoleń i dziesiątki osobowości i intelektualistów. Warto zauważyć, że pierwsza szkoła w Erbil kształciła Żydów, chrześcijan, muzułmanów, Kurdów, Arabów i Turkmenów bez jakiejkolwiek dyskryminacji.

Habsa Khan Naqib utworzył w Sulaymaniyah pierwszą szkołę dla dziewcząt w 1946 r. Otwarcie szkół w Kurdystanie przyczyniło się do rozwoju literatury dziecięcej, szczególnie poezji, ponieważ w szkołach uczy się dzieci pieśni narodowych i edukacyjnych, a nauczyciele jako

\footnotetext{
38 Nawzad Ali Ameen, op. cit., s. 21.

39 I.I. El Mosherfy, op. cit., s. 104.
} 
al songs and educational and the first pioneers of Kurdish children's poetry are teachers.

The poetry offers children an opportunity for the development of their feelings, emotions, and various psychological needs, as well as of their skills and taste. It educates children's minds, styling them, expanding their imagination and love for literature and the heritage of their country ${ }^{40}$.

\section{Conclusions}

According to the considerations above we can see that children's literature has played a great role in the composition of children's personalities, because it is so strongly involved in child-raising, spiritual development, and physical education, which undoubtedly supports the construction of an individual's personality. Moreover children's literature has an impact on children's language development, and language, as we have seen, is closely related to thinking.

Children's literature's popularity and development proves that literature has a great impact on the process of upbringing, building bonds with a motherland, answering questions about identity, explaining the world around children, expanding their vocabulary, shaping taste and a sense of humor and creating common symbols and values. Raising a child is not solely the duty of parents and school. Society and its culture play a huge role in the upbringing of a child, and it should also be our duty

\footnotetext{
40 Ibidem, p. 105.
}

pierwsi zapoznają dzieci kurdyjskie z poezją.

Poezja oferuje dzieciom możliwość rozwoju ich uczuć, emocji i różnych potrzeb psychologicznych, a także ich umiejętności. Edukuje umysły dziecięce, stylizuje je, rozwija ich wyobraźnię i miłość do literatury oraz dziedzictwa swego kraju ${ }^{40}$.

\section{Wnioski}

Zgodnie z powyższymi rozważaniami możemy zauważyć, że literatura dziecięca odgrywa dużą rolę w tworzeniu osobowości dziecka, ponieważ jest tak bardzo zaangażowana w wychowywanie dzieci, rozwój duchowy i wychowanie fizyczne, co niewątpliwie wspiera budowanie osobowości. Ponadto literatura dziecięca ma wpływ na rozwój języka dzieci, a język, jak można było zauważyć, jest ściśle związany z myśleniem.

Popularność i rozwój literatury dziecięcej dowodzi, że literatura ma ogromny wpływ na proces wychowywania, budowania więzi z ojczyzną, odpowiadania na pytania dotyczące tożsamości, wyjaśniania świata otaczającego dzieci, poszerzania słownictwa, kształtowania smaku i poczucia humoru oraz tworzenia wspólnych symboli i wartości. Wychowanie dziecka nie jest obowiązkiem tylko rodziców i szkoły. Społeczeństwo i jego kultura odgrywają ogromną rolę w kształtowaniu

40 Ibidem, s. 105. 
to raise mature adults who will participate in maintaining this culture in the future.

Children's literature offers many role models while teaching proper behavior in various situations. Children's admiration for the stories' heroes and actions encourage them to adopt similar behavior and patterns. Children's literature in stories, television, radio programs, and other venues helps children master the skills required from them: accuracy of observation, reflection, the desire to interpret questions, and solving problems. Kurdish children's literature roots should be sought in folk art, long before written art occurred. Nevertheless, in the shape we know it today, it has many factors including the historical, social and cultural. $\mathrm{Pa}$ triotic thought and its symbols seem to have played a great role in the upbringing of Kurdish children.

\section{Abstract}

Children's literature, despite being a relatively young branch of literature in general, is an important factor in the upbringing of children. Its basic aims have been obvious but not simple to achieve - to develop a child's personality, provide educational experiences and encourage him to read. Along with areas such as art, theater, puppetry, music, movement and field trips, literature is also an object of children's attention. Moreover it provides an opportunity to gain experience and learn a lesson, as children are usually open to fairytale-like content. Because of that, a magic world of adventures usually becomes a part of the educational process, imparting moral patterns and exposing them to various experiences, values dziecka - my także powinniśmy wychowywać dojrzałych dorosłych ludzi, którzy będą uczestniczyć w tworzeniu tej kultury w przyszłości.

Literatura dziecięca oferuje wiele modeli ról, jednocześnie ucząc właściwych zachowań w różnych sytuacjach. Podziw dzieci dla bohaterów i akcji opowieści zachęca je do naśladowania podobnych zachowań i wzorców. Literatura dziecięca w opowiadaniach, programach telewizyjnych, radiowych i wielu innych ułatwia dzieciom zdobycie niezbędnych umiejętności: dokładności obserwacji, refleksji, chęci interpretowania pytań i rozwiązywania problemów. Korzeni literatury dla dzieci kurdyjskich należy szukać w sztuce ludowej, na długo przed pojawieniem się sztuki pisarskiej. Niemniej, w dzisiejszej formie zawiera wiele czynników historycznych, społecznych i kulturalnych. Wydaje się, że myśl patriotyczna i jej symbole odegrały dużą rolę w wychowaniu dzieci kurdyjskich.

\section{Abstrakt}

Literatura dziecięca, mimo że jest stosunkowo młodą dziedziną literatury, odgrywa istotną rolę w procesie wychowywania dzieci. Jej podstawowe cele są oczywiste, ale niełatwe do osiągnięcia rozwijanie osobowości dziecka, dostarczanie doświadczeń edukacyjnych i zachęcanie go do czytania. Literatura, oprócz takich dziedzin, jak sztuka, teatr, lalkarstwo, muzyka, ruch i wycieczki szkolne, jest częścią świata dzieci. Ponadto daje możliwość zdobywania doświadczenia i wyciągania wniosków, ponieważ dzieci są zazwyczaj otwarte na bajkową treść. Z tego powodu magiczny świat przygód zwykle staje się częścią procesu edukacyjnego, podsuwając moralne wzorce i prezentując różne doświadczenia, wartości czy 
and attitudes. Listening to stories told by parents, nannies, and teachers, which are later read by children themselves, is an activity beloved by children from all over the world. This research focuses especially on Kurdish experiences in terms of children's literature and its role in bringing up a child. It indicates essential differences between contents, aims and circumstances upon which certain stories occurred. It provides an explanation of their role in developing a mature personality and patriotism ${ }^{41}$ upbringing among Kurdish children. postawy. Słuchanie opowieści, które najpierw prezentowane są przez rodziców, opiekunów i nauczycieli, a później czytane przez same dzieci, jest zajęciem ukochanym przez dzieci na całym świecie. Prezentowane badania koncentrują się przede wszystkim na doświadczeniu kurdyjskim w zakresie literatury dla dzieci i jej roli w wychowaniu dziecka. Wskazują na istotne różnice między treściami, celami i okolicznościami, w których wystąpiły określone opowiadania. Przedstawiają wyjaśnienie roli tych opowiadań w rozwijaniu dojrzałej osobowości i patriotyzmu ${ }^{41} \mathrm{w}$ procesie wychowania kurdyjskich dzieci.
41 "Patriotism" is a term used to express love for the homeland. Examples of national positions include the following: culture, pride, pride in accomplishments, the desire to preserve the character and the basis of culture, and identification with other members of the nation.
41 „Patriotyzm” jest pojęciem używanym do wyrażania miłości do ojczyzny. Przykłady postaw nacjonalistycznych obejmują: kulturę, dumę, dumę z osiągnięć, chęć zachowania charakteru i podstawy kultury oraz identyfikację z innymi członkami narodu.

\section{Bibliography / Bibliografia}

Abdul-majeed Qasim, Qsas Al-atfal w tajarbkurdiya, http://gilgamish.org/printarticle.php?id=2689 [access on: 11.10.2016].

Anderson A.N., Elementary Children's Literature: The Basics for Teachers and Parents, 2/E, Pearson 2005.

Burke C., Copenhaver J.G., Animals as People in Children's Literature, "Language Arts" 2004, vol. 81 , nr 3 .

Edmonds C.J., Kurdish Nationalism, http://journals.sagepub.com/doi/abs/10.1177/002200100600105 [access on: 11.10.2016].

Ergobek K.S., Mukhamedzhanova A.B., Sartbaeva D K., Karpykbaeva A.S., Bimaganbetova A.K., Patriotic upbringing of future teachers in the course of studying of the discipline "Children's literature", "Life Science Journal" 2014, 11.

Himdadi Husayni, Darwazay akbo Rakhnay Adabinwey Kurdi, Hawler 2010.

Eabdalnabi Aistif, AladabAlshaebi, https://www.arab-ency.com/ar/ [access on: 10.10.2016].

Harris G.S., Ethnic Conflict and the Kurds, "Annals of the American Academy of Political and Social Science" 1977.

Hamakarim Hawrami, Adabi Mndalany Kurd Lekolinawaw, MejuySarhaldan, Hawler 2005.

Huck C., Kiefer B., Hepler S., Hickman J., Children's literature in the elementary school, 8th ed., New York 2004.

Insherah Ibrahim El Mosherfy, Adab Al-atfal Madkhal Liltarbiya Al-ibdaeya, Alexandria 2005.

Nahida Ahmad, Saratayak darbaray sarhaldani adabi mndalani kurd, Hewler 2005.

Nawzad Ali Ameen, Mndal u Adab, Roon press, Sulaymaniya 2006.

Noyes D., The Social Base of Folklore, [in:] A Companion to Folklore, edit. R. Bendix, G. Hasan-Rokem, Malden 2012. 
Sarfaraz Nakshaband, A History of Kurdish Children's Literature, Paper presented at the EU, International P.E.N Conference Language, Literature and Culture of the Kurdish People Brussels, Belgium, 9-10 December 1999, translated by dr Zorab Aloian.

The Kurdish Project, http://thekurdishproject.org/history-and-culture/kurdish-culture/kurdish-folklore/ [access on: 12.10.2016].

The Encyclopedia of Incarnation, English 2006.

Zeynep N.K., Maps into Nations: Kurdistan, Kurdish Nationalism and International Society, London School of Economics and Political Science, London, June 2012.

Article submitted: 10.10.2016; article accepted: 10.02.2017 